\title{
SYMPOSIUM Pregnancy and Diseases of the Endocrine Glands
}

\section{Pregnancy and Diabetes Mellitus}

H. YOSHIDA

Medical Department of Kyoto Prefectural University of Medicine, Kyoto

(See pp. 611 620)

\section{Thyroid Disease and Pregnancy}

\section{Y. UEDA \& K. HAYASHI}

Department of Obstetrics and Gynecology, Kobe University School of Medicine, Kobe (See pp. 621 631)

\section{Some Aspects of Corticoids Metabolism during Pregnancy}

\section{F. AKASU}

Department of Obstetrics and Gynecology, School of Medicine, The University of Kanazawa, Kanazawa (See pp. 632 639)

Pituitary Gland with Special Reference to Post-partum Hypopituitarism (Sheehan's Syndrome)

\section{NISHIKAWA}

2nd Department of Medicine, Osaka University School of Medicine, Osaka (See pp. 640 646) 